\title{
Comparative Analysis of Selected Determinants of Innovation in EU Countries
}

\author{
Katarzyna BROŻEK \\ Kazimierz Pulaski University of Technology and Humanities in Radom, Radom, Poland \\ k.brozek@uthrad.pl
}

\begin{abstract}
Innovation is the key to the success of businesses and entire economies in today's world. And it should become a strategic target for the development of the EU economies. Undoubtedly, the creation of conditions for the development of innovation becomes the most important issue both from the perspective of an individual economic entity success and of the entire state. This issue is therefore extremely important in the micro and macroeconomic area. Bearing in mind that modern economies are transforming at an incredible rate, and at the same time, permanent sources of development are weakening, innovations, and above all their commercialization, are what the EU countries see as an effective solution to the problem of achieving economic growth. When analyzing selected determinants of innovation, it is impossible to underestimate their role and importance. Consequently, the subject matter is relevant both from theoretical as well as practical point of view.

The aim of the article is to deepen the definition and multifaceted examination of the relevance of selected determinants of innovation in EU countries. The essence of the research problem is therefore to examine the relationship between the level of innovation in EU countries and the following factors: GDP, number of applied patents, innovative products, or research and development expenditure. In the light of the theoretical research, the following were analyzed: the essence and definitions of innovation, the role and significance of innovation in the company.
\end{abstract}

Keywords: Analysis, Innovation, European Union.

\section{Theoretical approach to innovation}

\subsection{The essence and definitions of innovation}

There are many definitions of the subject in the literature, so it is important to find their common ground.

When analyzing the definitions of innovation, it is worthwhile to present the meaning of the word itself, which is derived from Latin. Innovatio or innovare means novelties or newly introduced things.

In the first years of functioning, the term innovation was seen in the macroeconomic context. It was analyzed how technological development affects the 
development of the economy. Over time, professionals have shifted away from perceiving innovation in macroeconomic terms, and microeconomic analysis has begun, where technological development has been perceived as a process.

The analysis of the problem of defining innovation is as follows: among foreign authors it is necessary to mention: J. Schumpeter [21], F. Machlup [15], P. Kotler [13], R. W. Griffin [7], S. Jobs [5], P. R. Whitfield [24], R. Johnston [12], S. Shane [23], P. Drucker [1], [2], Ch. Freeman [4], E. Helpman [9], M. E. Porter [19]. In contrast, among Polish authors taking up this subject, one can distinguish, among others: Z. Pietrasiński [17], W. Grudzewski and I. Hejduk [8], A. Pomykalski [18], Z. Madej [10], A. Jasiński [11] and M. Goławska [6].

The concept of innovation was introduced by the Austrian economist Joseph Schumpeter at the beginning of the 20th century. His definition is the foundation on which the other terms are based, yet it is extremely versatile and current in the present day. The creator based the innovation on the following pillars [26]:

- introduction of new goods that consumers have not yet known or a new product of some kind;

- introducing a new method of production that has not yet been practically tested in the particular industry;

- opening up a new market, i.e. a market where a given type of industry of the relevant country was not previously introduced, regardless of whether the market existed before or not;

- gaining a new source of raw materials or semi-finished products, regardless of whether the source already existed or had to be created;

- Conducting a new organization of an industry, such as creating a monopoly or breaking it [20].

Schumpeter's theory can be summarized as the introduction of new methods. Typically, they were related to technology, but the use of imitation, i.e. the dissemination, implementation and use of new methods, was significant.

Innovation can also be seen as an economically successful exploitation of new ideas [19].

The multitude of different views for innovations made F. Machlup to look for other solutions. He said that in such a situation, we should be able to cope without using the word "innovation" if we are able to find more definite words [15].

P. Kotler stated that innovation refers to any good, service or idea which is perceived by someone as new. The idea can exist for a long time, but it is an innovation for the person who perceives it as new [13].

R. W. Griffin treated that innovation should be introduced by a company as an effort aimed at developing new products / services or making a whole new use of products / services that already exist in the market [7].

For S. Jobs innovation does not refer only to technology, it also deals with ideas that help solve problems. The founder of Apple thought there was no system that could create innovation. He said that a person who forces themselves to invent something innovative is “ like somebody who's not cool trying to be cool. It's painful 
to watch..." [5]. S. Jobs created seven principles which could accelerate creating process of innovation:

- Do what you love - follow your heart and passion;

- Put a dent in the universe - attract other people who want to create amazing things;

- Make connections - get a wide experience and connect facts;

- Say no to 1000 things - simplicity is a sign of sophistication;

- Create insanely different experiences - create deep, lasting emotions;

- Master the message - the launch of a product should be a form of art

- Sell dreams, not products - create products that will allow people to fulfill their dreams [5].

P. R. Whitfield has an interesting way of defining innovation as he pointed to the process of complex work that is based on finding solutions to problems. The effect of this is the development of novelty [24].

Researchers also had a different opinion on whether innovation can be considered at the time of introducing a new product, as Schumpeter and his imitation are concerned, or innovation as well as any further improvement of an existing product. The representative of the second mainstream was undoubtedly R. Johnston [12]. Similarly, in the western world, researchers in Poland have been wondering how to define innovation. The first works began in the 1960s. The study was limited to the technical context because of the specificity of the market in a socialist state where the economy was centrally planned.

Z. Pietrasiński, for whom "innovations are deliberately introduced by human beings or by cybernetic systems designed by them, which are substituting previous states of things that are positively assessed in the light of certain criteria and which also create a progress" [17].

Schumpeter's perception of innovation was also shared by W. Grudzewski and I. Hejduk, for whom innovation, every activity, or product, which is new, qualitatively different from existing ones was an innovation.[8].

A. Pomykalski, on the other hand, was leaning toward the Johnston's model, where innovation is part of improvement of given solution or a product [18].

Z. Madej believed that innovation must not always carry a positive load, affecting the development of the company [10]. Thus, his perception was beyond the framework of the concepts that were presented in the above examples. He created a definition that is somewhat aberration of the old way of thinking.

In addition to the above condensed presentation of the term innovation is Table 1, which contains the most popular researchers in innovation theory and the keywords that are included in their definitions. It can be seen that the basis of most of the analyzed definitions is "novelty" and "product" - (they occurred seven times), it becomes the main determinant of introducing the innovation in the enterprise. It is also worth noting that among the eleven selected researchers of this problem, much less frequent (because 4 times) the word "service" has appeared, and "improvement" only 3 times. Incidentally, such terms as "good", "idea", "imitation", "failure", "progress" and "commodity" were scattered. 
Table 1. Keywords of the term innovation by selected authorities of economic sciences.

\begin{tabular}{ll}
\hline Creator & Keywords \\
\hline J. Schumpeter & novelty, product, commodity, imitation \\
F. Machlup & rejection of the word innovation \\
Oslo Mannual & novelty, improvement, product, process \\
P. Kotler & novelty, good, service, idea, product \\
R. W. Griffin & development, novelty, product, service, use \\
S. Jobs & idea, lack of innovation system creation \\
P. R. Whitfield & workflow, problem resolution, novelty \\
R. Johnston & product improvement \\
W. Grudzewski, I. Hejduk & novelty, product, service, distinction from existing forms \\
Z. Madej & novelty, improvement, failure \\
Z. Pietrasiński & positive changes in products, services; progress \\
& \\
\hline
\end{tabular}

\subsection{The role and importance of innovation in the enterprise}

At present, the dynamics of changes taking place in developed countries has led to the emergence of postmodern economy, network economy and, in particular, knowledgebased economy. These terms may have different, sometimes distinct, meanings, and each of them can be understood in a variety of ways, leading to a perception of the essence of the present economic systems. The distinguishing feature of the developed countries economy is the increase in the share of the services sector in employment and formation of GDP (so-called servitization of the economy). Moreover, in the described systems, the fundamental factor of economic growth of the country and the enterprises operating therein are: knowledge and innovations. So their role in the aspect of building the economic structure of the country is extremely important. It can also be noted that the formal and informal relations of all members operating in the economic space are important.

The role of innovation in development, not just of enterprises but of the economy as a whole, is indisputable, and many researches can prove that. For authors of Global Competitiveness Report 2016-2017, innovation is a part of the twelve pillars of economic competitiveness [22].

Implementing new products / processes that will be approved by consumers can lead to increased returns on sales, while the use of process innovation can reduce production costs.

In today's aggressively competitive market, companies must work on a high level of innovation [16], which will distinguish them from other economic operators and thus allow them to survive on the market.

The overriding role of innovation is to increase the value of the company [25] that leads to its development. It should be borne in mind that the value of an economic entity should be related to what the company can achieve in the future [14], that is why long-term planning and innovation management must be established. 


\section{The impact of selected factors on the level of innovation in $\mathbf{E U}$ countries}

The impact on the level of innovation can be influenced by factors such as: GDP, PCT patent applications, SMEs introducing product or process innovations, or expenditure on research and development. The relationship between these factors is analyzed below. Table 2 shows these aspects on the example of EU Member States in 2015-2016. The highest average number of introducing product or process innovations registered in Belgium, it was $0.789 \%$ and in Finland $0.714 \%$, while the lowest in Romania $0.000 \%$ and Poland $0.030 \%$. In terms of patent applications, the highest percentage was recorded in Sweden at 1.000 PPS and in Finland at 0.977 PPS. The lowest percentage was recorded in Romania 0.170 PPS and Slovakia 0.244 PPS. Unfortunately, Poland also fell in the group of countries whose index was one of the lowest and amounted to only 0.249 PPS.

Table 2. Selected indicators of product innovation and macro-economic measures for the EU28 in 2015-2016 [3].

\begin{tabular}{|c|c|c|c|c|c|}
\hline Country & $\begin{array}{c}\text { SMEs } \\
\text { introducin } \\
\text { g product } \\
\text { or process } \\
\text { innovations } \\
\text { (percentag } \\
\text { e of SMEs) }\end{array}$ & $\begin{array}{l}\text { PCT patent } \\
\text { applications } \\
\text { per billion } \\
\text { GDP (in } \\
\text { PPS) }\end{array}$ & $\begin{array}{c}\text { R\&D } \\
\text { expenditure } \\
\text { in the } \\
\text { business } \\
\text { sector } \\
\text { (percentage } \\
\text { of GDP) } \\
\end{array}$ & $\begin{array}{c}\text { R\&D } \\
\text { expenditur } \\
\mathrm{e} \text { in the } \\
\text { public } \\
\text { sector } \\
\text { (percentage } \\
\text { of GDP) } \\
\end{array}$ & $\begin{array}{l}\text { GDP (in mln } \\
\text { euro) }\end{array}$ \\
\hline Austria & 0.622 & 0.738 & 0.846 & 0.815 & 348895.05 \\
\hline Belgium & 0.789 & 0.612 & 0.684 & 0.597 & 416741.8 \\
\hline Bulgaria & 0.045 & 0.253 & 0.231 & 0.115 & 46707.55 \\
\hline Croatia & 0.275 & 0.255 & 0.152 & 0.289 & 45403.3 \\
\hline Cyprus & 0.453 & 0.282 & 0.022 & 0.171 & 17932.25 \\
\hline $\begin{array}{c}\text { Czech } \\
\text { Republic }\end{array}$ & 0.448 & 0.345 & 0.416 & 0.798 & 172518.8 \\
\hline Denmark & 0.530 & 0.830 & 0.728 & 1.000 & 274633.4 \\
\hline Estonia & 0.314 & 0.380 & 0.250 & 0.709 & 20723 \\
\hline Finland & 0.714 & 0.977 & 0.797 & 0.916 & 212598 \\
\hline France & 0.521 & 0.678 & 0.562 & 0.658 & 2211550 \\
\hline Germany & 0.712 & 0.842 & 0.759 & 0.871 & 3093850 \\
\hline Greece & 0.479 & 0.245 & 0.108 & 0.479 & 175255.65 \\
\hline Hungary & 0.049 & 0.383 & 0.381 & 0.227 & 112226.85 \\
\hline Ireland & 0.681 & 0.522 & 0.420 & 0.244 & 268802.25 \\
\hline Italy & 0.564 & 0.488 & 0.286 & 0.457 & 1666337.65 \\
\hline Latvia & 0.045 & 0.260 & 0.067 & 0.339 & 24639.9 \\
\hline
\end{tabular}




\begin{tabular}{|c|c|c|c|c|c|}
\hline Lithuania & 0.307 & 0.292 & 0.108 & 0.653 & 38047.45 \\
\hline Luxembourg & 0.665 & 0.438 & 0.258 & 0.513 & 52553.35 \\
\hline Malta & 0.414 & 0.350 & 0.144 & 0.227 & 9608.8 \\
\hline Netherlands & 0.710 & 0.806 & 0.432 & 0.821 & 693049 \\
\hline Poland & 0.030 & 0.249 & 0.170 & 0.406 & 428017.45 \\
\hline Portugal & 0.669 & 0.282 & 0.227 & 0.569 & 182494.3 \\
\hline Romania & 0.000 & 0.170 & 0.063 & 0.104 & 164945.9 \\
\hline Slovakia & 0.125 & 0.244 & 0.118 & 0.608 & 80025.2 \\
\hline Slovenia & 0.397 & 0.598 & 0.686 & 0.423 & 39627.35 \\
\hline Spain & 0.157 & 0.415 & 0.244 & 0.468 & 1099260 \\
\hline Sweden & 0.669 & 1.000 & 0.854 & 0.955 & 457107.7 \\
\hline $\begin{array}{c}\text { United } \\
\text { Kingdom } \\
\end{array}$ & 0.432 & 0.607 & 0.426 & 0.446 & 2497636.55 \\
\hline
\end{tabular}

When analyzing the level of $\mathrm{R} \& \mathrm{D}$ expenditure in the business sector, it should be noted that the leader in the ranking was Sweden at $0.854 \%$ of GDP and Austria at 0.846 of GDP. The lowest recorded countries in this respect were Cyprus with $0.022 \%$ of GDP and Romania with $0.063 \%$ of GDP. Poland, as in the case of patent applications, came in second to last with $0.170 \%$ of GDP.

Considering the GDP level, the highest values were obtained in countries such as Germany (over $€ 3.09$ trillion) and Great Britain and France, whose values were $€ 2.49$ trillion and $€ 2.21$ trillion, respectively. Table 3 presents the results of the correlation coefficient between GDP and individual innovation indicators.

Table 3. Results of the correlation coefficient between GDP and individual innovation rates in the EU-28 countries in 2015-2016.

\begin{tabular}{|c|c|}
\hline $\begin{array}{l}\text { GDP and R\&D expenditure in the public sector (percentage of } \\
\text { GDP) }\end{array}$ & 0.24 \\
\hline $\begin{array}{l}\text { GDP and R\&D expenditure in the public business (percentage } \\
\text { of GDP) }\end{array}$ & $\mathbf{0 . 3 3}$ \\
\hline GDP and PCT patent applications per billion GDP (in PPS) & 0.42 \\
\hline $\begin{array}{c}\text { GDP and SMEs introducing product or process innovations } \\
\text { (percentage of SMEs) }\end{array}$ & 0.27 \\
\hline
\end{tabular}

Pearson's correlation coefficient for the relationship between the country's GDP and $R \& D$ expenditure in the public sector was $r=0.24$. Correlation is therefore plus / positive, and the relationship is very weak. In the case of the relationship between GDP and R\&D expenditure in the public sector, $r=0.33$, which proves that the correlation is plus / positive and the relationship is very weak. As for the correlation between the GDP and PCT patent applications per billion GDP, it was $r=0.42$; which means that it is plus / positive, and the relationship moderately strong. In the last case 
correlation coefficient for the relationship between the GDP and SMEs introducing product or process innovations was $r=0.27$. Correlation is plus / positive, and the relationship is very weak. Figure 1 is a supplement to the analysis because the scattering between the examined data is shown.

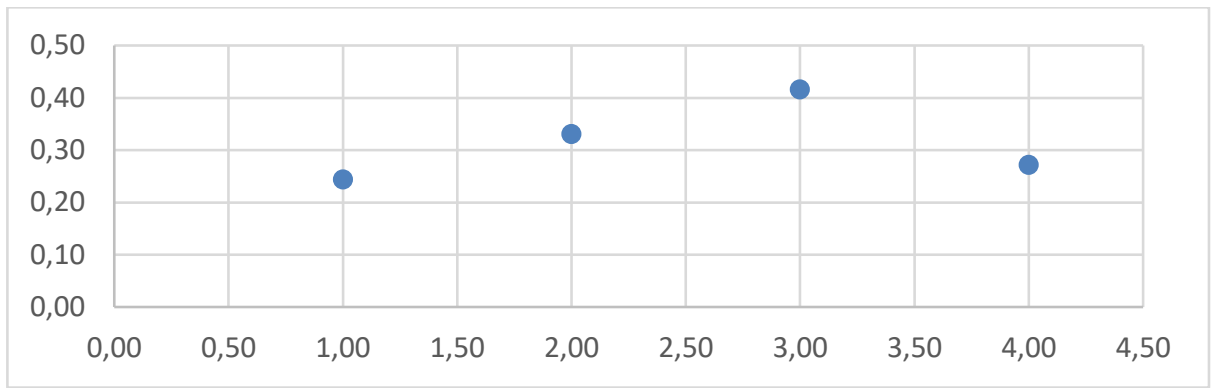

Fig. 1. The relationship between GDP and individual innovation rates in the EU-28 countries in 2015-2016.

In the next stage, further dependencies were investigated, but this time they concerned PCT patent applications. The strength of the relationship between PCT patent applications per billion GDP and R \& D expenditure were also examined. It should be noted that, as in previous analysis, all positive correlation coefficients were obtained, so that in each analyzed case a positive correlation was obtained. The coefficient of the first tested relationship (i.e. between PCT patent applications per billion GDP and $\mathrm{R} \& \mathrm{D}$ expenditure in the public sector) was $\mathrm{r}=0.73$; so the relationship is very strong. The analysis of the relationship between PCT patent applications per billion GDP and R \& D expenditure in business sector was characterized by a correlation coefficient of: $r=0.91$, and therefore a very strong relationship. The analysis is detailed in Table 4 and Figure 2, which shows the scattering between the surveyed data.

Table 4. Results of the correlation coefficient between PCT patent applications per billion GDP (in PPS) and R \& D expenditure in EU-28 countries in 2015-2016

\begin{tabular}{cc}
\hline $\begin{array}{c}\text { PCT patent applications per billion GDP (in PPS) and R \& D } \\
\text { expenditure in the public sector (percentage of GDP) }\end{array}$ & $\mathbf{0 . 7 3}$ \\
$\begin{array}{c}\text { PCT patent applications per billion GDP (in PPS) and R \& D } \\
\text { expenditure in the business sector (percentage of GDP) }\end{array}$ & $\mathbf{0 . 9 1}$ \\
\hline
\end{tabular}




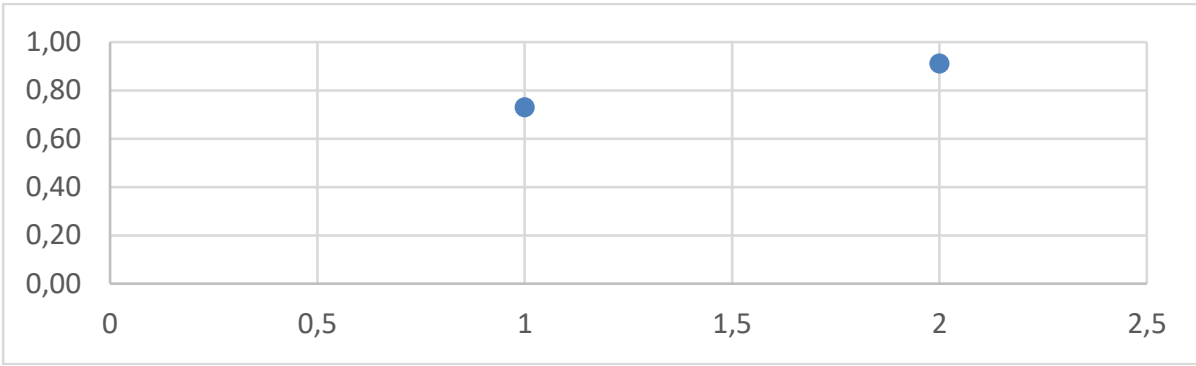

Fig. 2. The relationship between PCT patent applications per billion GDP (in PPS) and R \& D expenditure in EU-28 countries in 2015-2016

In the next phase, further dependencies were investigated, but this time they concerned SMEs introducing product or process innovations. The strength of the relationship between SMEs introducing product or process innovations and the two selected R \& D indicators were also examined. It should be noted that, as in previous analysis, all positive correlation coefficients were obtained, so that in each analyzed case a positive correlation was obtained. The coefficient of the first tested relationship (i.e. SMEs introducing product or process innovations and R \& D expenditure in the public sector) was $\mathrm{r}=0.58$; so the relationship is strong. The analysis of the relationship between SMEs introducing product or process innovations and R\&D expenditure in the business sector was characterized by a correlation coefficient of: $r$ $=0.62$, and therefore a strong relationship. The analysis is detailed in Table 5 and Figure 3, which shows the scattering between the surveyed data.

Table 5. Results of the correlation coefficient between SMEs introducing product or process innovations (percentage of SMEs) and R \& D expenditure in EU-28 countries in 2015-2016

SMEs introducing product or process innovations (percentage of SMEs) and R \& D expenditure in the public sector (percentage of GDP)

SMEs introducing product or process innovations (percentage of SMEs) and R \& D expenditure in the business sector 


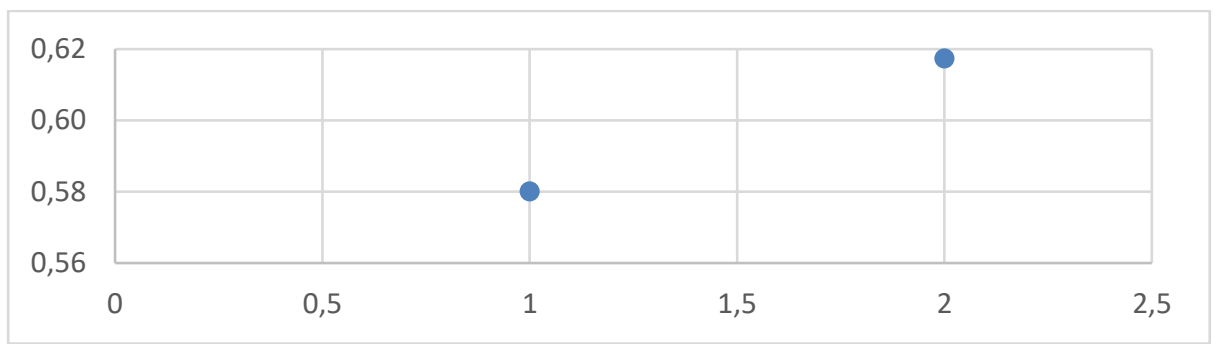

Fig. 3. The relationship between SMEs introducing product or process innovations (percentage of SMEs) and R \& D expenditure in EU-28 countries in 2015-2016

The above analysis suggests that in every case, together with increasing GDP or PCT patent applications, there is an increase in all tested innovation ratios. However, it should be borne in mind that in each case the relationships between the individual elements are strong. In many cases, the development of innovation may be linked to the economic situation of a particular country. Therefore, the economic factor may be significant, but its complement should be, for example, the knowledge and experience of human capital. It can be stated that this idea and the involvement of employees together with adequate financial contribution are the appropriate catalyst for the formation of new products / processes.

\section{Summary and conclusions}

Innovations are present in every aspect of life today. They reflect the dynamic changes taking place in the world. One can get the impression that every successive product or every next thought is related to innovation, and consequently the meaning has to some degree been depreciated. This word is often used by marketing agencies, which in the dynamically developing markets are trying to overtake the competition.

Comparative analysis of selected determinants of innovation in EU countries has been started with three indicators of innovation, namely: R \& D expenditure, PCT patent applications and SMEs introducing product or process innovations. The research period was limited to two years (i.e. 2015-2016) and the innovation rates were reported by twenty-eight EU countries. The stated purpose of the discussions was achieved by applying statistical analysis, with particular emphasis on the use of Pearson's correlation coefficient. The study was divided into three phases. The first focused on demonstrating the strength of the relationship between GDP and (separately) the three selected indicators of innovation. On the other hand, the second part of the analysis was to determine the scale of dependence between PCT patent applications and R \& D expenditures in the public and business sector. The third stage of the analysis was to present the strength of the relationship between SMEs introducing product or process innovations and R \& D expenditures in the public and business sector.

Correlation analysis allowed us to identify the most important innovation determinant of all the surveyed ones. The strongest correlation was with the number 
of PCT patent applications. For both in the first case, when examining the correlation index between the number of PCT patent applications and R \& D expenditure in the public and business sector, were analyzed, correlation coefficients showing a very strong correlation between the tested variables were obtained. There was a positive correlation, so both features grew or diminished in the same direction.

Moderately strong relationship depicted SMEs introducing product or process innovations and R \& D expenditure in the public and business sector. On the other hand, the lowest correlation coefficient results were obtained when comparing R \& D expenditure in the public sector and GDP and SMEs introducing product or process innovations and GDP. So there was a very weak connection between these features. Therefore, on the basis of the obtained results, it can be stated that the innovative products new for the market are the least important determinants.

The above analysis demonstrates that the country's GDP is not as strong factor enhancing innovation as it is shown to the general public consciousness. Obviously, as the Gross Domestic Product grows, the index of innovation is growing, but their impact is not as large.

However, it is important for SMEs which are introducing innovative products or processes and patent applications to have financial support from public organizations or government. It will involve more specialists and provide special equipment for research centers and laboratories that will allow engineers to design and implement new ideas and products.

The proposed analysis does not exhaust the totality of the examined matter, but it is an indication of the rightness to continue further and extend the research in this field.

\section{References}

1. Drucker, P.F.: Innowacje i przedsiębiorczość. Praktyka i zasady, PWE, Warsaw (1992).

2. Drucker, P.F.: Natchnienie i fart czyli innowacja i przedsiębiorczość, Wydawnictwo Studio Emka, Warsaw (2004).

3. Eurostat, http://ec.europa.eu, last accessed 2017/04/02.

4. Freeman, Ch.: The Economics of Technical Changes, In: Cambridge Journal of Economics $18,463-513,(1994)$

5. Gallo, C.: The innovation secret of Steve Jobs, The McGraw-Hill Companies, New York (2011).

6. Goławska, M.: Koncepcja innowacyjności, In: Marketing i rynek 11, 39, Warsaw (2004).

7. Griffin, R.W.: Podstawy zarządzania organizacjami, PWN, Warsaw (2005).

8. Grudzewski, W., Hejduk, I.: Przedsiębiorstwo przyszłości, Difin, Warsaw (2000).

9. Helpman, E. Grossman, G.: Innovation and growth in the global economy, MIT Press, Cambridge (1993).

10. Janasz, W., Kozioł, K.: Determinanty działalności innowacyjnej przedsiębiorstw, PWE, Warsaw (2007).

11. Jasiński, A.: Innowacje i transfer techniki w procesie transformacji, Difin, Warsaw (2006).

12. Johnston, R. (1966). Technical Progress And Innovation. Oxford Economic Papers 18(2), 158-176, http://dx.doi.org/10.1093/oxfordjournals.oep.a041016.

13. Kotler, P.: Marketing. Analiza, planowanie, wdrażanie i kontrola, Gebethner i Ska, Warsaw (1994). 
14. Kuc, B.R., Paszkowski, J.: Organizacja - wartości - zarządzanie, In: OrechwaMaliszewska, E., Paszkowski, J. (eds.), Zarządzanie wartością organizacji, pp. 17. Wydawnictwo Wyższa Szkoła Finansów i Zarządzania w Białymstoku, Bialystok (2007).

15. Machlup, F.: The Production and Distribution of Knowledge in the United States, Princeton, New Jersey (1962).

16. Marakova, V., Dyr, T., Wolak-Tuzimek, A.: Factors of Tourism's Competitiveness in the European Union Countries. Ekonomika a management 19(3), 92-94, (2016).

17. Pietrasiński, Z.: Ogólne i psychologiczne zagadnienia innowacji, PWN, Warsaw (1971).

18. Pomykalski, A.: Zarządzanie innowacjami, Wydawnictwo Naukowe PWN, Warsaw-Lodz (2001).

19. Porter, M.E.: The Competitive Advantage of Nations, The Macmillan Press Ltd., London (1990).

20. Schumpeter, J.: Teoria rozwoju gospodarczego, PWN, Warsaw (1960).

21. Schumpeter, J.A.: Business Cycles. A Theoretical, Historical and Statistical Analysis of the Capitalist Process, McGraw Hill, New York (1964).

22. World Economic Forum, http://www3.weforum.org/docs/GCR20162017/05FullReport/TheGlobalCompetitivenessReport2016-2017_FINAL.pdf, last accessed 2017/10/26

23. Shane, S.: A General Theory of Entrepreneurship. The Individual-Opportunity Nexus, Edward Elgar Publishing Limited, UK (2003).

24. Whitfield, P.R.: Innowacje w przemyśle, PWE, Warsaw (1979).

25. Wolak-Tuzimek, A., Duda, J., Sołoma, A., Lament, M.: Zarządzanie małym i średnim przedsiębiorstwem. Wybrane problemy, Instytut Naukowo-Wydawniczy Spatium, Radom (2015).

26. Wolak-Tuzimek, A.: Innovative Activities of Small and Medium-Sized Enterprises in Poland. In: Löster, T., Pavelka, T. (eds.) The 10th International Days of Statistics and Economics, pp. 2057-2058. , Melandrium Prague (2016). 